\title{
THE PRESERVATION AND DISSEMINATION STRATEGY OF TOBA BATAK INDIGENOUS KNOWLEDGE FOR MILLENIAL GENERATIONS
}

\author{
Afryna Veronica* \\ *Program Studi Perpustakaan dan Sains Informasi, Universitas Sumatera Utara \\ Email: afryna.veronica@usu.ac.id
}

(Submitted: 22-07-2019, Revised: 23-03-2020, Accepted: 01-03-2021)

DOI: $10.24252 / v 9 i 1 \mathrm{a} 2$

\begin{abstract}
ABSTRAK: Era kini merupakan era di mana setiap orang tidak dapat dipisahkan dari pengetahuan. Indigenous Knowlegde (IK) atau kearifan lokal merupakan salah satu dari pengetahuan yang belum terdokumentasikan. Penelitian ini menganalisis tentang strategi preservasi dan diseminasi IK bagi generasi millennial Suku Toba Batak yang ada di perantauan. Penelitian ini difokuskan pada preservasi dan diseminasi IK yaitu bahasa dan aksara Toba Batak. Metode yang digunakan dalam penelitian ini yaitu metode penelitian kualitatif, di mana pengumpulan data menggunakan observasi, wawancara, dan analisis dokumen. Hasil dari penelitian ini ialah dalam preservasi dan diseminasi bahasa dan aksara Toba Batak menggunakan teori World Bank yang terdiri dari enam langkah masih ditemui beberapa kendala. Kendala ini yang menyebabkan banyak dari masyarakat Toba Batak di perantauan lebih memilih untuk tidak membagikan dan mendesiminasikan bahasa dan aksara Toba Batak ini kepada generasi masa kini/millenial. Hal yang sangat disayangkan karena IK ini merupakan identitas diri bangsa.
\end{abstract}

Kata kunci: Kearifan lokal, pelestarian bahan pustaka, penyebaran informasi

ABSTRACT: The present era is an era where everyone cannot be separated from knowledge. Indigenous Knowledge (IK) is one of the undocumented knowledges. This study analyzes IK preservation and dissemination strategy for the millennial generation of the Toba Batak tribe who are living overseas. This research is focused on the preservation and dissemination of IK, namely the Toba Batak language and script. The method used in this study is a qualitative research method, where data collection obtained through observation, interviews, and document analysis. The result of the study is that in the preservation and dissemination of the Toba Batak language and script using the World Bank theory which consists of six steps, some obstacles are still encountered. This obstacle causes many of the Toba Batak tribe overseas to prefer not to share and disseminate the Toba Batak language and script for the current generation/millennials. It is very unfortunate because the Toba Batak language and script are a national identity.

Keywords: Indigenous knowedge; library collections preservation; dissemination information

\section{INTRODUCTION}

The current era of information disclosure makes everyone to easily access information and knowledge. According to Kim (2000), knowledge is divided into two types; explicit and implicit knowledge. The knowledge that has been documented and disseminated is called explicit knowledge, while knowledge that is unstructured, undocumented, and cannot be clearly stated is implicit knowledge. The implicit knowledge is also called tacit knowledge. This form of knowledge is known as indigenous knowledge (IK), (Msuya, 2007) and (Semali, 2002). 
The terms 'traditional', 'local' and 'indigenous' knowledge are used in the literature interchangeably. However, the term of 'indigenous knowledge' seems to have become more familiar than other terms. Indigenous knowledge (IK) is also being misused for some categories of information produced indigenously. The development of local literature databases, creation of institutional repositories, and other activities focusing on managing certain categories of National information output as reported by Sukula (2006), TJiek (2006), and some other writers should not come within the purview of IK. Indigenous knowledge has been defined as 'the local knowledge that is unique to a given culture or society', (Anwar, 2010).

As stated in his article published in the International Review of Information Ethics, Jangawe Msuya described local knowledge as follows: "Indigenous knowledge (IK) is defined as a systematic body of knowledge acquired by local people through the accumulation of experiences, informal experiments and intimate understanding of the environment in a given culture", (Msuya, 2007). Based on that, it can be said that IK is a form of knowledge possessed by local and indigenous people and is still traditional.

Indonesia is a country with wealth of indigenous knowledges. This IK is in the form of a very diverse and invaluable cultural heritage. Every area, every community in the Nation has its own indigenous knowledge. According to statistical data of 2010 Indonesia Population Census, it was reported that Indonesia has approximately of 17 thousand islands, 1500 tribes, and 1027 languages. One of tribes is Toba Batak tribe that owned its indigenous knowledge. Toba Batak tribe has multiple types of IK, two of which are its language and script. The language and script are media used by the tribe to express, communicate, and make daily relationships either in the form of writing, oral, or gestures.

IK is reflected in the habits of life that have been occured for a long time. The sustainability of this IK will be seen in the values prevailing in a particular community group. These values are held by these community groups, which usually become an inseparable part of life and can be observed through their daily attitudes and behavior. In other words, the IK then becomes part of their wise way of life to solve all life problems they face. Thanks to IK, they can continue their lives, even be more developed and sustainable (Discourse to Explore Civilization, 2011).

Currently, the existence of Toba Batak language and script is threatened due to the fact that the IK has not time to be preserved and disseminated to the next generation. Besides, many people who have this IK have passed away. In addition to the two things mentioned, the displacement of Toba Batak tribes to other areas also affects the threat of extinction. In their new place, they began to be affected by the assimilation and caused the IK they had to be different from the IK in Toba Batak community in their hometown. This threat is often found in big cities where Toba Batak community migrants live.

It would be a pity if the IK that had been known for a long time and was recognized as a national identity has ended up being extinct just because of some of the factors mentioned. However, the preservation efforts, especially Toba Batak language and script, are very lacking, especially for Toba Batak millennial generation who live overseas. Therefore, this paper is interested in discussing the strategy of transferring and disseminating of the IK of Toba Batak language and script for Toba Batak millennial generation.

\section{PREVIOUS FINDINGS}

The concept of strategy was initially commonly used in the military, then adopted and adapted by the business world. Currently, the strategy is used to bridge the goals and means. Nickols (2012) defines strategy as a framework that guides choices in determining the nature and direction of an organization. According to his paper a strategy is perspective, plan, and position. A strategy is considered as a bridge link between policy objectives with tactics or concrete actions. It is also in line with Hunger (2003) who stated that strategy is a series of managerial decisions and actions that determine the company's long-term performance. Hariadi (2005), explained that the strategy consists of two stages: formulation and implementation. The formulation stage is the process of preparing the steps that will be taken to realize the vision and 
mission. While the implementation stage is the strategic process carried out following the steps that have been determined in the previous formulation stage.

\section{The Indigenous Knowledge of Toba Batak Tribe}

In his paper, Jangawe Msuya (2007) argues that indigenous knowledge is defined as a systematic body of knowledge acquired by local people through the accumulation of experiences, informal experiments and intimate understanding of the environment in a given culture. Based on that, it can be said that local knowledge is actual knowledge, which is generally passed from generation to generation through orally stories. According to Johnson in Msuya (2007), it identifies several characters from local wisdom, as follows:

1) IK is the knowledge that comes from the local area,

2) IK is a culture and in a specific context,

3) IK is informal knowledge,

4) IK is the knowledge that is disseminated through speech, in general it is not documented,

5) IK is the dynamic and adaptive knowledge, which changes along with social, economic, and cultural changes in society.

6) The essential nature of IK is holistic,

7) IK belongs to a community.

Toba Batak tribe is a sub or part of the Batak tribe. Toba Batak tribe include Toba Samosir, Humbang Hasundutan, Samosir, North Tapanuli, a part of Dairi, Central Tapanuli, Sibolga and the surrounding areas (Discourse to Explore Civilization, 2011). This tribe is an indigenous tribe of Indonesia and has historical value of IK. The IK owned by Toba Batak tribe refers to the knowledge and practices of indigenous peoples that develop from their experiences. Furthermore, this IK is transferred orally from generation to generation. Their IK is managed through several forms such as folk tales, folk songs, proverbs, cultural values, religions, rituals, community law, regional languages, and animal descent. The IK is also used in particular fields that are very important for people's lives such as agricultures, fisheries, health, horticulture, and forestry.

Toba Batak tribe have clans that show the identity of which offspring they come from. This surname is obtained from the father's lineage (patrilineal) which will then be passed on to male descendants continuously. According to Batak people's opinion, 'child (boy)' is the king, while 'boru' (daughter) means that the clan breaks up there. Toba Batak tribe, like other Batak ethnic groups, have had a habit of living nomadically everywhere. Until now Toba Batak tribe are still like to travel to other areas in all parts of Indonesia and abroad. Because of this custom of migrating, Toba Batak community is known everywhere. Therefore, the migrating influences the existence of the IK of Toba Batak tribe, particularly the language and script. As a fact, at the current generation, many of the younger Toba Batak generations overseas tend not to use and learn their own mother language and script. This is proof that Toba Batak community have been gradually elevating their own indigenous knowledge.

\section{Toba Batak Language and Script}

Toba Batak language is one of local languages in Indonesia which is mainly spoken in the Lake Toba area and its surroundings. Herman Neubronner van der Tuuk, one of the early pioneers of research focusing on Toba Batak language, has written the Bible in Toba Batak language. While Toba Batak script is the letters or writing used to write Toba Batak languages (Wacana Explore Civilization, 2011). However, from the local folklore, their ancestors, Siraja Batak, was the first to carve Batak characters to write Batak language. Siraja Batak had not known that there were other languages besides his mother tongue. Batak people known other languages after spreading to other areas and began to know that there were other languages and characters they encountered outside Batak Tano. According to this local story, Batak script was not used in writing media such as on stone (in the form of inscriptions) or on metal plates but is more widely used in the form of bamboo tubes, bark, and also paper. Based on the folklore, at least a 
picture can be drawn that Batak language and characters are original, not borrowed, and are the creation of the Batak people themselves (Rose, September 2016).

\section{Toba Batak Millennial Generation Overseas}

Millennial generations are the hope of future leaders. Millennials are those who now live in an era of the disclosure of information, no longer limited by space and time in interacting one another. However, it is important to note that the disclosure of information has made some forget their identity. In fact, it can be seen that the millennial generations are poor in understanding, maintaining, and preserving the culture of their respective regions, particularly in this study is Toba Batak tribe IK. Nowadays, most of this generation do not care about the preservation of Toba Batak language and script due to their lack of knowledge of their IK. One of the reasons causes is that the millennial generations prefer to migrate to other places. They are accustomed to interacting with people of different ethnicities, so carried away and are preferred to use Bahasa Indonesia and even international languages which are compulsory curriculum in schools while the IK is ignored.

The crisis of identity has caused some of Toba Batak millennial generation to easily follow and join whatever is attracted on them, including western cultures that have influenced in many parts of Indonesia, and is considered better than preserving Toba Batak language and script itself. In addition to, many millennial generations felt embarrassed using Toba Batak language overseas. On the other hand, the community's views have an impact on the existence of Toba Batak IK. Most parents overseas consider Toba Batak language and script as IK that are not important to be taught to the younger generation. This is a real problem and really happened to Toba Batak community in Depok, West Java, where the advices of old parents have not touched the young generation today. If this problem is not taken seriously, the IK will be vanished.

\section{RESEARCH METHODOLGY}

According to Creswell (2009), data collection is an attempt to limit research, collect information through structured and unstructured observations and interviews, and attempt to design protocols for recording and recording information. The data were obtained through three ways; observation, interviews, and literature studies. The primary data was collected through field observations and interviews with the informants. As a preliminary study, this research was conducted to identify strategies for transferring and disseminating IK Toba Batak language and script for Toba Batak millennial generation overseas.

Qualitative research is a type of study in which the researcher is highly dependent on information from the object/participant in a broad scope, general questions, data collection mainly consists of words/texts from participants, explains and analyzes the words, and conducts research subjectively (Creswell, 2008). The study used a qualitative approach to determine how to find, collect, process, and analyze research data. Every qualitative research has an object and research subject. The subjects are three generations in a Toba Batak tribe family in Depok, West Java, categorized as grandmothers (85 years); mothers (50 years); and children (16 years). While the object of research is transferring and disseminating of IK in Toba Batak Tribe. This research was conducted in Depok, West Java in January.

\section{RESULTS AND FINDINGS}

\section{Capturing and Preserving Indigenous Knowledge}

Indigenous knowledge looks easy to be shared among community members, such as transferring knowledge from parents to children, but transferring and disseminating IK is a challenge in itself (World Bank, 2008). The process of exchanging IK involves the following six steps (World Bank):

1) Recognition and identification, which may not be accessible in certain situations and might involve social and technical analysis;

2) Validation in terms of its relevance, reliability, functionality, effectiveness and transferability; 
3) Recording and documenting in view of the intended use of information using audiovisual technology, taped narration, drawings, or other forms of codifiable information;

4) Storage which will involve categorization, indexing, relating it to other information, making it accessible and conserving, preserving and maintaining it in the form of retrievable repositories for later use;

5) Transferring means making it available to the potential users for testing in the new environment; and

6) Dissemination to the broader community through appropriate channels of communication.

According to that, it can be seen that the conservation of Toba Batak's IK has been preserved but has not been maximized. The steps that have been taken are as follows:

\section{Recognition and Identification of IK Activities}

This activity is to identify and recognize oral traditions in the community. The recognition and identification of IK activities carried out by Toba Batak community who live overseas, are as follows: (1) The use of Toba Batak in the Huria Kristen Batak Protestant (HKBP) church, (2) There is a kinship community in Toba Batak clan, for example Punguan Sihombing Boru Dohot Bere in the Central Jakarta (Semarga Group). For example, Punguan community use Toba Batak language to communicate.

\section{IK Validation Activities}

This activity is an assessment of the IK by looking at the source's relevance, function, and authenticity. The validation activities of the IK in Toba Batak language can be seen from Toba Batak's proverb, which is commonly called Umpasa Ni Halak Batak. These proverbs are still used and relevant to the life of Toba Batak people today, an example, "santau aek nuaeng, duaan tahu aek marsogot, na santahu i do pareahan", means "no matter what we produce today, maybe tomorrow will be more, but today's little results, we should be grateful", (Flowers, September 2016). Such a proverb is preserved based on knowledge from generation to generation.

\section{Recording and Documenting IK Activities}

This activity is a way to convert tacit knowledge to explicit by transforming it into new media. The Government of North Sumatra has carried out recording and documenting Toba Batak language and script. It can be seen from the functional of the Historical Museum to record the entire Toba Batak culture; there is a Toba Batak Center for arts and culture in the Samosir District; and the presence of the Batak Literature Department's in the University of North Sumatra.

\section{Activities to Store IK}

This activity is the process of storing IK that has been recorded and documented in repository. The media used in storage range from books, CDs, databases, and other various information media. The activity of saving IK is also studied and published in certain journals and other scientific works discussing Toba Batak tribe IK. As for the transfer and dissemination of IK in Toba Batak language and script, the cultivation of Toba Batak community in Toba Lake area and its surroundings (North Sumatra) is stronger than the people overseas. This is evident from the younger generation in North Sumatra prioritizing their IK standards.

\section{Transferring and Dissemination of Toba Batak Language and Script}

IK preservation activities through transferring and dissemination are one way that can be done to maintain Toba Batak language and script. However, this activity has not occurred overseas. Most of the younger generation have never been introduced to Toba Batak script. Apart from the fact that several younger generations use English more often at home than Toba Batak language. Following are the interviews with few younger generations of Toba Batak in Depok, West Java. 
"I never used Toba Batak language at home, never knew about Batak script either", (Edelwais, interview in September 2016)

"My parents never taught me to speak Toba Batak or Toba Batak script. I think it's too important", (Dodo, interview in September 2016)

"I was accustomed to using English at home by my parents, because they think that speaking English is an important thing", (Ratna, interview in September 2016)

It can be said that most of Toba Batak younger generations living in Depok are lack of understanding about their own IK. Nevertheless, the younger generations of Toba Batak overseas have not completely forgotten the IK. For example, there is a collection of a clan's younger generation called Punguan Naposo Sihombing throughout Depok City. Punguan aims to strengthen, build a kinship, and a place to confide each other for the same clan bond. Punguan is very beneficial for the young generation overseas. If young generations migrate and do not have a biological family in their new place, through Punguan they might still have a family and can communicate with each other without feeling far from home.

It is unfortunate to say that there has not been any transferring and dissemination of IK in Toba Batak language and script for the younger generations. They know their origins and their kinship. In fact, the young generations have not used Toba Batak language during communication. They do not realize that Toba Batak language and script are identity that must be preserved and taught.

\section{CONCLUSION}

Basen on what explained above, the indigenous knowledge of Toba Batak can only be understood through the language and script of Toba Batak. In addition, Toba Batak language and script are the identity of Toba Batak tribe that need to be preserved and taught. Through this research, indeed, the transferring and dissemination of IK towards Toba Batak language and literature has not occurred in the younger generation overseas. It can be seen that many young people who cannot use or do not understand Toba Batak language in communication and unable to write its script. This IK transferring and dissemination strategy aims to strengthen the identity of Toba Batak tribe that most believe it has an essential value for the community, especially for the millennial generations of Toba Batak tribe who live in overseas.

It is recommended that the only way to conserve the IK is to practice it together. Toba Batak community living overseas might teach their children or the young generations. Thus, the preservation of this IK is maintained from time to time. Besides, If the millennial generations pay more attention on Toba Batak language and script, their own IK will not be vanished in today information disclosure. It is due to the IK is very influential and believed might influence the behavior of the future generations. Furthermore, the IK documentation activities are really important and might be continuously carried out, particularly to the future generations, and protect IK as intellectual property assets.

\section{REFERENCES}

Creswell, J. (2008). Educational Research Planning, Conducting, and Evaluating Qualitative and Qualitative Research. Yogyakarta: Pustaka Belajar.

-. (2009). Research Design Pendekatan Penelitian Kualitatif, Kuantitatif, dan Mixed. Yogyakarta: Pustaka Pelajar.

-. (2014). Research design: qualitative, quantitative and mixed methodsapproache. Sage Publications.

Departemen Pendidikan Nasional. (2003). Undang-Undang Nomor 20 Tahun 2003, . Jakarta: Depdiknas.

Depdikbud. (2004). Pedoman Perpustakaan Perguruan Tinggi. Jakarta: Departemen Pendidikan dan Kebudayaan. 
Hainer, B. B. (2014). Rethinking library resource sharing: new models for collaboration. Emerald Insight.

Johnson, P. (2014). Fundamentals of Collection Development and Management. Chicago: American Library Association.

Muthu, M. (2013). Resource Sharing In Libraries: A Vital Role of Consortia. Journal of Library and Information Science.

Reitz, J. M. (2004). Dictionary for Library and Information Science. Westport, Connecticut London: Libraries Unlimited.

Smith, D. (2014). Collaborative resource sharing between public and school libraries. Emerald Insight.

Sulistyo-Basuki. (1993). Pengantar Ilmu Perpustakaan. Jakarta: Gramedia Pustaka Utama. 